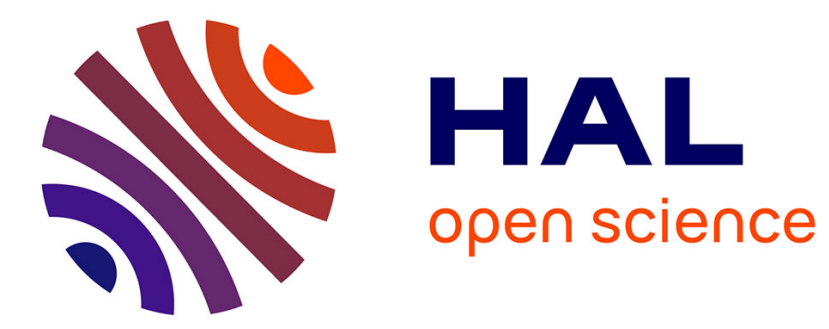

\title{
WHISKER-REINFORCED OXIDE CERAMICS
}

N. Claussen, G. Petzow

\section{To cite this version:}

N. Claussen, G. Petzow. WHISKER-REINFORCED OXIDE CERAMICS. Journal de Physique Colloques, 1986, 47 (C1), pp.C1-693-C1-702. 10.1051/jphyscol:19861106 . jpa-00225501

\section{HAL Id: jpa-00225501 https://hal.science/jpa-00225501}

Submitted on 1 Jan 1986

HAL is a multi-disciplinary open access archive for the deposit and dissemination of scientific research documents, whether they are published or not. The documents may come from teaching and research institutions in France or abroad, or from public or private research centers.
L'archive ouverte pluridisciplinaire HAL, est destinée au dépôt et à la diffusion de documents scientifiques de niveau recherche, publiés ou non, émanant des établissements d'enseignement et de recherche français ou étrangers, des laboratoires publics ou privés. 


\title{
WHISKER-REINFORCED OXIDE CERAMICS
}

\author{
N. CLAUSSEN and G. PETZOW* \\ Technische Universität Hamburg-Harburg, P.O.B. 901403, \\ D-2100 Hamburg 90, F.R.G. \\ "Max-Planck-Institut für Metallforschung, Heisenbergstrasse 5 , \\ D-7000 stuttgart 80, F.R.G.
}

\begin{abstract}
Résumé - Le renforcement par wiskers est une technique prometteuse pour l'amélioration significative des propriétés mécaniques des céramiques aussi bien pour les applications à haute température qu'à basse température. Les exemples discutés dans cet article concernent des matrices d'Al $\mathrm{O}_{3}$, cordiérite, mullite et zircone; toutes sont renforcées de wiskers de SiC.
\end{abstract}

\begin{abstract}
Whisker reinforcement represents a promising technique to significantly improve the mechanical behavior of oxide ceramics both for low and high temperature applications. Examples discussed in the paper include the matrix materials $\mathrm{Al}_{2} \mathrm{O}_{3}$, cordierite, mullite and $\mathrm{ZrO}_{2}$; all reinforced with SiC whiskers.
\end{abstract}

\section{I - INTRODUCTION}

Structural oxide ceramics are limited in their application not only because of their brittle nature, but also because of the hightemperature creep performance which is inferior to the covalently bonded ceramics. Transformation toughening has been successfully applied to a number of oxides $/ 1 /$. However, the effectivity of this toughening mechanism decreases with increasing temperature, becoming ineffective at $\mathrm{T}>\sim 700^{\circ} \mathrm{C}$. Fiber reinforcement offers the opportunity to achieve valuable strength and toughness improvements both at low and high temperatures. This has been demonstrated mainly with glass and glass ceramic matrices $/ 2 /$. For high-strength crystalline oxides, whiskers are a better choice than fibers because of their ability to survive the severe hot-pressing conditions necessary for incorporation into ceramic matrices /3-5/. The whiskers presently available have diameters of the same order of magnitude as the grain size of most of the strong oxides, their strengths and Young's moduli are much higher than those of the fibers, there are no out-gassing nor grain-growth problems as associated with fibers $/ 6 /$ and normal ceramic powder processing can be applied without thermally and mechanically degrading the whisker properties $/ 7 /$.

Another attraction of introducing whiskers is the prospect of increasing the room temperature strength of some transformation 
toughened materials, especially tetragonal Zro 2 polycrystals (TZP) and PSZ, where the strength is not controlled by the largest flaw but by the mean eritical stress required to initiate the tranformation $18,9 /$. This is schematically indicated in Fig. 1. E.g., Ce-TZP/10/ with a toughness of $-500 \mathrm{MPa} \sqrt{\mathrm{m}}$ and a strength of only $-500 \mathrm{MPa}$ (right side of strength / toughness area) could be considerably strengthened by the incorporation of whiskers whithout loss in tough-

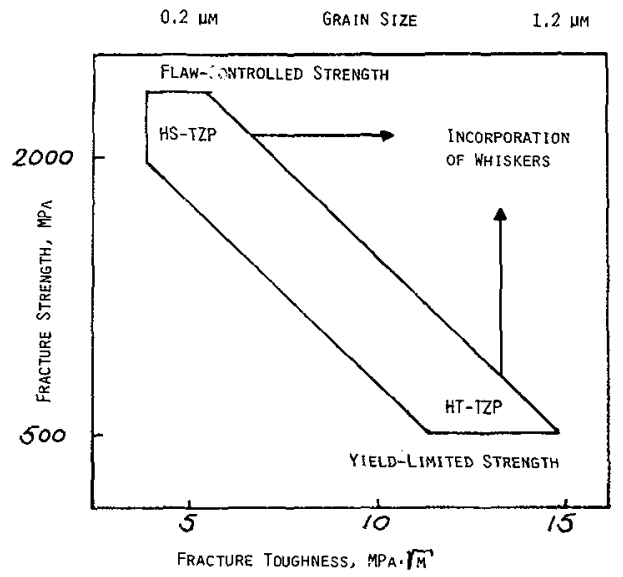

Fig. 1 - Schematic diagram of strength toughness relation in TzP ceramics. The numbers represent the approximate range of values anticipated for $2-4$ mole $\% \mathrm{Y}_{2} \mathrm{O}_{3}-\mathrm{TZP}$.

ness. On th other hand, fine-grained, high-strength TZP could be toughened by the whiskers, however, with some loss in strength if the thermal mismatch between whiskers and the TZP matrix produces tensile stresses in the matrix /11/.

The intend of the present work was to investigate possible preparation techniques to achieve a homogeneous whisker distribution and to study the effect of thermal mismatch on toughness and strength, mainly of $\mathrm{ZrO}_{2}$ - containing oxides. SiC whiskers were used in most cases.

\section{II - EXPERIMENTAL PROCEDURE}

For most experiments in the present work, SiC whiskers of grade SCW-1 ("separated and dispersion improved") from Tateho Chem. Ind., Kariya, Japan, were used. The property data given for these whiskers by the supplier are a composition of - $95 \%$-SiC, an impurity content (\%) of $0.15 \mathrm{Mg}, 0.25 \mathrm{Ca}, 0.31 \mathrm{Al}, 0.04 \mathrm{Fe}$, a range of diameters from 0.06 to $0.2 \mu \mathrm{m}$ and a range of lengths from 10 to $40 \mu \mathrm{m}$. Because the lot also contained larger Sic particles ( $>5 \mathrm{\mu m}$ ), the whiskers were first ultrasonically dispersed in isopropanol and deagglomerated in a tumbling mixer with plastic balls $(3 \mathrm{~mm} \emptyset)$ for $24 \mathrm{~h}$. Thereafter, most of the fragments $>5 \mu \mathrm{m}$ were eliminated by sedimentation. In two exploratory experiments were $\mathrm{Al}_{2} \mathrm{O}_{3}$ whiskers. (Thermokinetics, Washington, D.C.) and $\mathrm{Si}_{3} \mathrm{~N}_{4}$ whiskers (SNW-1, Tateho) incorporated into TZP. and cordierite. 
The ceramic matrix powders used for the oxide ceramic/whisker composites are given in Table 1. The cordierite is an experimental, fully crystallized powder which is readily sinterable. The other materials are well-characterized standard grades.

Table 1: Ceramic powders used for the whisker composites

\begin{tabular}{|l|l|l|}
\hline Ceramic & Type & Supplier \\
\hline $\mathrm{Al}_{2} \mathrm{O}_{3}$ & A16 & Alcoa, USA \\
Mulitie & Dynamullite (fused) & Dynamit-Nobel, FRG \\
Cordierite & experimental & Schott Glaswerke, FRG \\
m- $\mathrm{ZrO}_{2}$ & SC 20 & MEL, U. K. \\
t- $\mathrm{ZrO}_{2}$ & TSK 3 (3 mole $\left.\% \mathrm{Y}_{2} \mathrm{O}_{3}\right)$ & Toyo Soda, Japan \\
\hline
\end{tabular}

Ceramic Powder

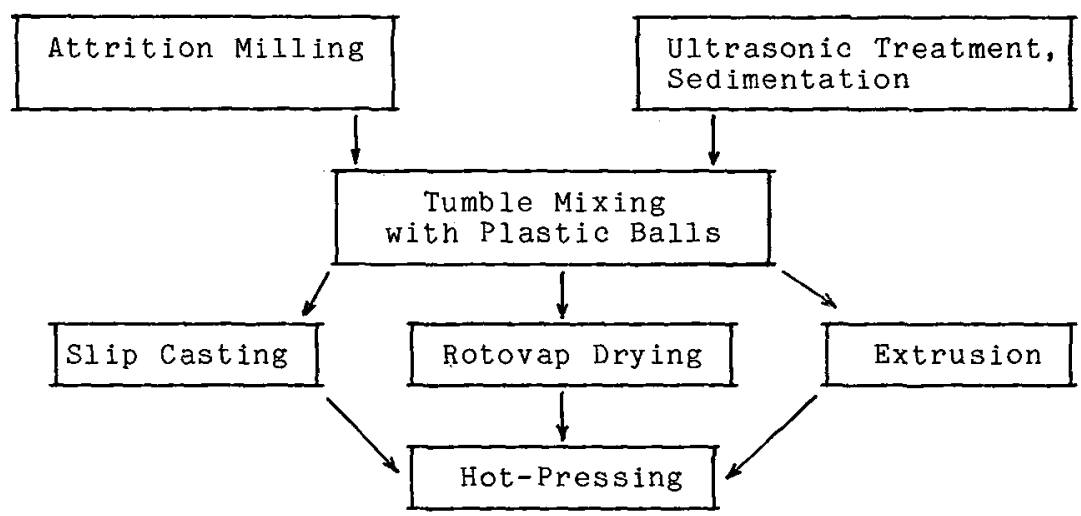

Fig. 2 - Processing of the whisker Composites.

The processing of the composites is summarized in Fig. 2. All matrix compositions with and without $\mathrm{ZrO}_{2}$ additions were attrition milled for $2 \mathrm{~h}$ in isopropanol using TZP balls for the $\mathrm{Al}_{2} \mathrm{O}_{3}$ and cordierite composites and $\mathrm{Al}_{2} \mathrm{O}_{3}-\mathrm{SiO}_{2}$ balls for the TZP and mulite composites. The whisker powder slurries were then tumble mixed with $3 . \mathrm{mm}$ plastic balls. In most cases, the mixtures were dried in a rotovap dryer followed by uniaxial hot-pressing in BN-washed graphite dies. The hot-pressing conditions were $30 \mathrm{~min}$. at $1550^{\circ} \mathrm{C}$ for $\mathrm{Al}_{2} \mathrm{O}_{3}, 30 \mathrm{~min}$. at $1600^{\circ} \mathrm{C}$ for mullite, $10 \mathrm{~min}$. at $1300^{\circ} \mathrm{C}$ for cordierite and $10 \mathrm{~min}$. at $1450^{\circ} \mathrm{C}$ for TZP composites. In a few experiments, extrusion through a hypodermic syringe with a $1 \mathrm{~mm}$ orifice was tested with a plasticized mullite/whisker mixture as a mean of achieving uniaxial alignment of the whiskers. In this case, packages of aligned extruded rods were hot-pressed (Fig. 3).

The hot-pressed discs ( $35 \mathrm{~mm}$ in dia., $10 \mathrm{~mm}$ thick) were cut into rectangular bend bars $(30 \times 30 \times 2.5 \mathrm{~mm})$ : The fracture toughness was measured by the ISB technique in 4-point bending. Controlled flaws were introduced by Vickers indentation with loads of between 10 and $1250 \mathrm{~N}$. The fracture strength was measured in 4-point bending $(20 / 7 \mathrm{~mm})$, the orientation being such that the tensile surface was perpendicular to the HP direction. Six specimens were tested for each set of conditions.

The fracture surfaces were analyzed by SEM, and the microstructure was examined by TEM and STEM. 


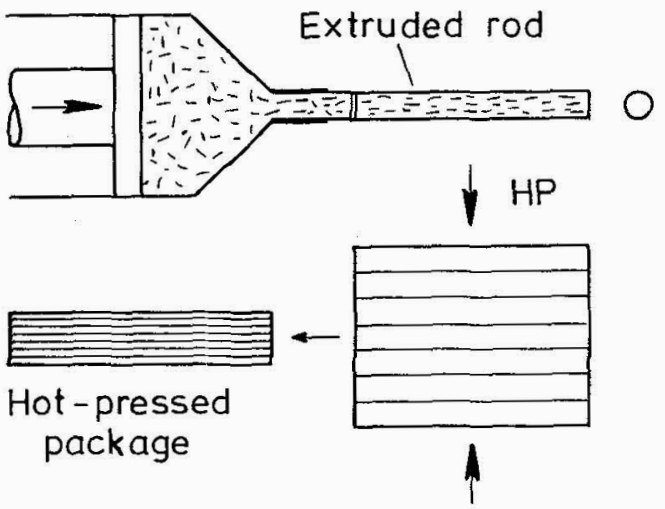

Fig. 3 - Schematic of uniaxial alignment of whiskers by hotpressing packages of extruded ceramic whisker rods.

\section{III - RESULTS AND DISCUSSION}

The processing conditions used resulted in almost theoretically dense composites with very homogeneous distribution of the whiskers. The preferred long-axis orientation of the whiskers was on planes perpendicular to the hot-pressing direction (whisker-plane). The overview optical micrograph in Fig. 4 a shows a whisker plane in a 10 vol. $\mathrm{ZrO}_{2}$ muIIite composite with 20 vol. \% Sic whiskers: The TEM overview of a 30 vol. \% SiC whisker/TZP. material (Fig. $4 \mathrm{~b}$ ) also demonstrates the homogeneity of the whisker distribution/11/. Fracture of whiskers was rarely observed. Reactions between the SiC whiskers and the ceramic matrices studied could not be detected, as was also the case for $\mathrm{Al}_{2} \mathrm{O}_{3}$ whiskers in TZP. Si ${ }_{3} \mathrm{~N}_{4}$ whiskers, however, reacted severely with $\mathrm{ZrO}_{2}$-containing materials.

Results obtained with the various oxide matrix/Sic whisker systems are discussed in the following paragraphs.
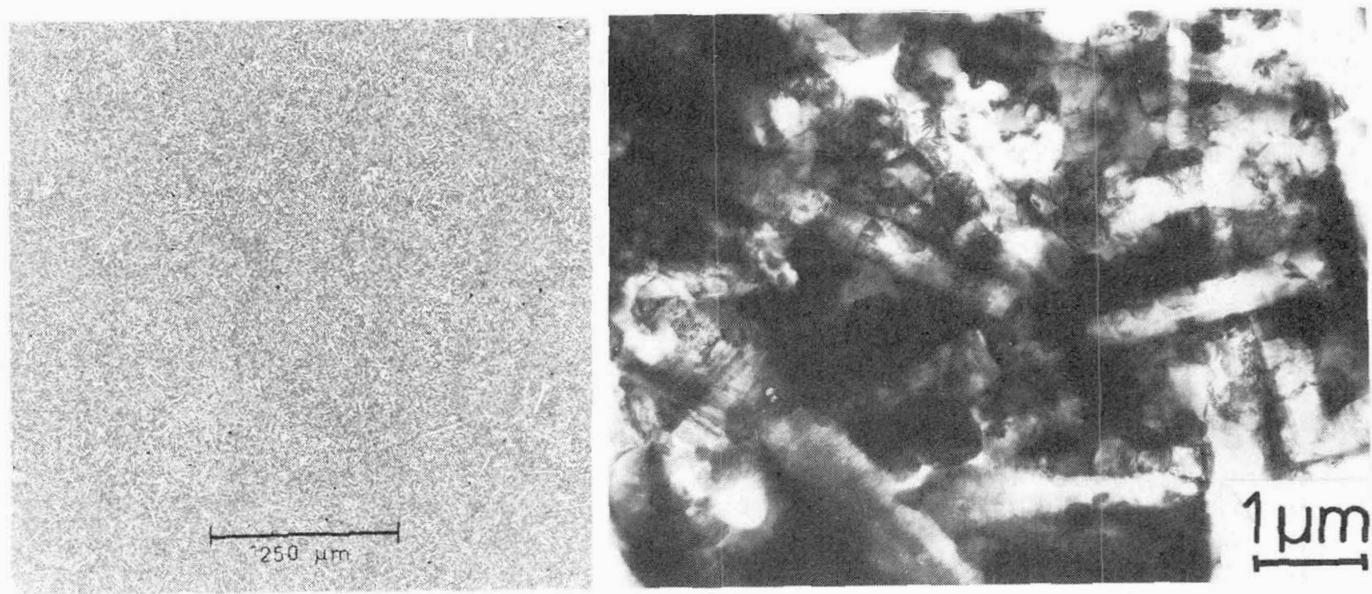

Fig. 4 - Microsections of "whisker planes" in a) 10 vol. \% $\mathrm{ZrO}_{2}$ mullite composite with 30 vol. \% SiC whiskers (LM) and b) TZP/30 vol. \% SiC whisker composite (TEM): 


\section{a) $\mathrm{Al}_{2} \mathrm{O}_{3} / \mathrm{SiC}$ whisker composites}

Table 2 lists strength and toughness data obtained at room temperature. For comparison, data from Ref. 12 are also included. The latter values, however, were obtained with different materials under different hot-pressing conditions.

Table 2: Strength and toughness of $\mathrm{Al}_{2} \mathrm{O}_{3} / \mathrm{SiC}$ whisker composites.

\begin{tabular}{|c|c|c|c|c|}
\hline No. & $\begin{array}{l}\text { Composition, vol. } \% \\
\text { Matrix }\end{array}$ & Whisker & $\begin{array}{r}\mathrm{K} I \mathrm{c} \\
\mathrm{MPa} \sqrt{\mathrm{m}}\end{array}$ & $\begin{array}{l}\text { Strength } \\
\mathrm{MPa}\end{array}$ \\
\hline $\begin{array}{l}1 \\
2 \\
3 \\
4 \\
5 \\
6 \\
7 \\
8\end{array}$ & $\begin{array}{l}\mathrm{Al}_{2} \mathrm{O}_{3} \\
\mathrm{Al}_{2} \mathrm{O}_{3} \\
\mathrm{Al}_{2} \mathrm{O}_{3}+15 \mathrm{t}-\mathrm{ZrO}_{2} \\
\left(\mathrm{Al}_{2} \mathrm{O}_{3}+15 \mathrm{t}-\mathrm{ZrO}_{2}\right) \\
\mathrm{Al}_{2} \mathrm{O}_{3}+40 \mathrm{~m}-\mathrm{ZrO}_{2} \\
\left(\mathrm{Al}_{2} \mathrm{O}_{3}+40 \mathrm{~m}-\mathrm{ZrO}_{2}\right) \\
\quad \mathrm{m}-\mathrm{ZrO}_{2} \\
\quad \mathrm{~m}-\mathrm{ZrO}_{2}\end{array}$ & $\begin{array}{l}+20 \mathrm{SiC} \\
+20 \mathrm{SiC} \\
+20 \mathrm{SiC} \\
+20 \mathrm{SiC}\end{array}$ & $\begin{array}{l}4.7 \\
8.5^{* *} \\
6.2 \\
13.5^{+} \\
2 \\
8.5 \\
<i^{++} \\
9.0^{++}\end{array}$ & $\begin{array}{c}520 \\
650 * \\
1080^{* *} \\
-700 \\
- \\
880 \\
- \\
\text { n. }\end{array}$ \\
\hline
\end{tabular}

The addition of $t-\mathrm{ZrO}_{2}$ to $\mathrm{Al}_{2} \mathrm{O}_{3}$ is more effective in increasing the strength than the toughness, a feature which is due to the refined microstructure /13/. On the other hand, whisker reinforcement results in remarkable toughness enhancement, although the strength increase is less pronounced. This fact can be explained by the high tensile matrix stresses due to the thermal mismatch between $\mathrm{Al}_{2} \mathrm{O}_{3}\left(\alpha_{\mathrm{m}}=8.5\right.$ $\left.\mathrm{MK}^{-1}\right)$ and $\operatorname{SiC}\left(\alpha_{\mathrm{W}}=4.7 \mathrm{MK}^{-1}\right)$. An average value of $485 \mathrm{MPa}$ for theses stresses may be estimated /4/. In addition, the effect of a larger critical flaw size due to some whisker clustering has to be considered.

The combination of the two toughening methods (No 4 in Table 2) yields a toughness increase $(-9.0$. MPa $\sqrt{\mathrm{m}})$ which is much more than the sum of the two single toughness increments (see Table 2, No 2: $3.8 \mathrm{MPa} \sqrt{\mathrm{m}}$ and No $3: 1.5 \mathrm{MPa} \sqrt{\mathrm{m}})$. Hence, the existence of a positive interaction between transformation toughening and whisker reinforcement appears to be evidenced by the results.

The same arguments as for the No 2 composite apply to the strength of the No 4 composite. Further increases in strength should be possible by reducing the thermal mismatch stresses, e.g., by introducing $\mathrm{Al}_{2} \mathrm{O}_{3}$ whiskers or by utilizing the phase transformation (see chapter IV).

SEM evaluation of the fracture surfaces suggests crack deflection as the main whisker toughening mechanism. Pull-out was rarely observed.

b) mullite/SiC whisker composites

Room temperature strength and toughness data are given in Table 3 . In mullite composites, whisker and $\mathrm{ZrO}_{2}$ toughening appear to be additive. There is no obvious additional interaction effect. Since the thermal mismatch is negligible between mullite and SiC, the strength and $\mathrm{K}_{\mathrm{Ic}}$ are improved to the same degree. The relatively low strength of the aligned whisker composites (Nos. 6 and 7 in Table 3, Fig. 5), may be explained by the fact that stress singularities at strongly bonded whiskers can lead to premature failure and that crack deflection is less effective as a mechanism if the crack plane is perpendi- 
cular to the whiskers. At high temperature, when whisker pull-out may become effective due to interface softening, the aligned composites may exhibit superior strengths.

Table 3: Strength and toughness of mullite/SiC whisker composites.

\begin{tabular}{|c|c|c|c|c|}
\hline No & $\begin{array}{l}\text { Composition, vol. \% } \\
\text { Matrix }\end{array}$ & Whisker & $\mathrm{K}_{\mathrm{Ic}}, \mathrm{MPa} \sqrt{\mathrm{m}}$ & Strength, MPa \\
\hline $\begin{array}{l}1 \\
2\end{array}$ & $\begin{array}{l}\text { Mullite } \\
\text { Mullite }+10 \mathrm{ZrO}_{2}\end{array}$ & & $\begin{array}{l}2.8 \\
3.5\end{array}$ & 244 \\
\hline 3 & Mullite & $+20 \mathrm{SiC}$ & 4.4 & 452 \\
\hline 4 & (Mullite $\left.+10 \mathrm{ZrO}_{2}\right)$ & $+20 \mathrm{SiC}$ & 5.4 & 580 \\
\hline & (Mullite $\left.102 \mathrm{rO}_{2}\right)$ & $+30 \mathrm{SiC}$ & 6.7 & 551 \\
\hline & Mullite & $+10 \mathrm{SiC}$ & 4.1 & 277 \\
\hline 7 & Mullite & +20 SiC & 4.6 & 407 \\
\hline
\end{tabular}
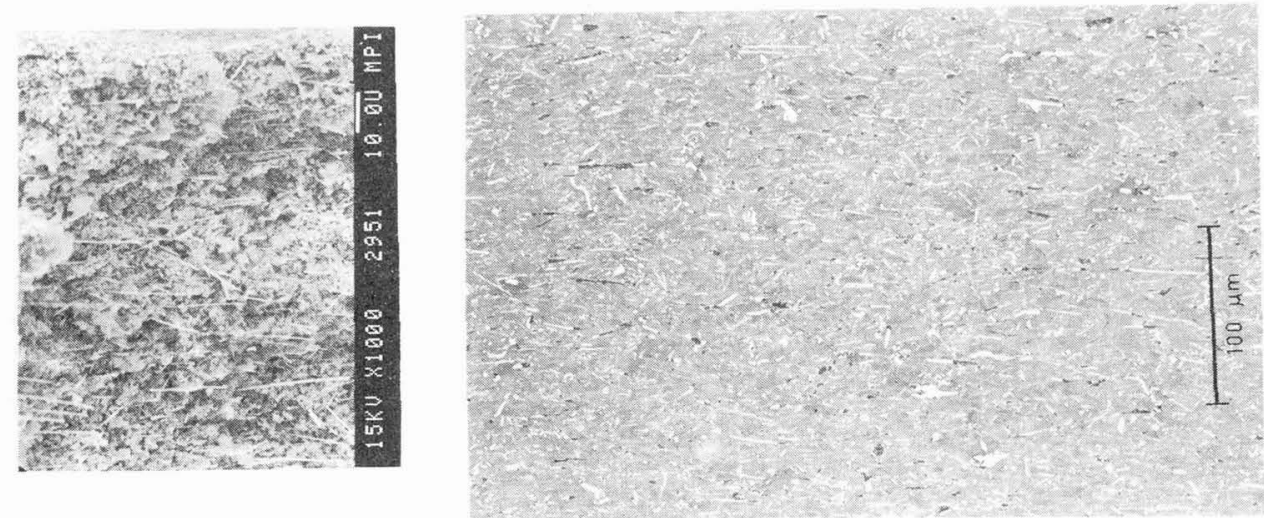

Fig. 5 - Mullite/10 vo1. \% SiC whisker composite extruded through a $1 \mathrm{~mm}$ orifice of a hypodermic syringe.

a) SEM fractograph of the green extruded rod and

b) microsection of the "whisker plane".

c) Cordierite/SiC whisker composites

Table 4 gives some preliminary $\mathrm{K}_{\mathrm{Ic}}$ and strength results obtained at room temperature and at $1000^{\circ} \mathrm{C}$.

Table 4: Strength and toughness of cordienite/SiC whisker composites.

\begin{tabular}{|c|c|c|c|c|c|}
\hline No & $\begin{array}{l}\text { Composition, vol. } \% \\
\text { Matrix }\end{array}$ & Whisker & $\mathrm{K}_{\mathrm{Ic}}, \underset{\mathrm{RT}}{\mathrm{MPa} \sqrt{\mathrm{m}}}$ & $\begin{array}{l}\text { Strength, } \\
\text { RT }\end{array}$ & $\begin{array}{l}\mathrm{MPa} \\
1000^{\circ} \mathrm{C}\end{array}$ \\
\hline $\begin{array}{l}1 * \\
2 \\
3 * \\
4\end{array}$ & $\begin{array}{l}\text { Cordierite } \\
\text { Cordierite }+20 \quad \mathrm{ZrO}_{2} \\
\text { Cordierite } \\
\text { (Cordierite }+2 \mathrm{O}^{\mathrm{ZrO}} 2 \text { ) }\end{array}$ & $\begin{array}{l}+20 \mathrm{SiC} \\
+20 \mathrm{SiC}\end{array}$ & $\begin{array}{l}2.2 \\
\text { n.d. } \\
3.7 \\
\text { n.d. }\end{array}$ & $\begin{array}{l}180 \\
190 \\
260 \\
380\end{array}$ & $\begin{array}{l}170 \\
160 \\
245 \\
300\end{array}$ \\
\hline
\end{tabular}

* Hot pressed at $1250^{\circ} \mathrm{C}$ for $30 \mathrm{~min}$.

The favorable thermal mismatch becomes obvious from the greatly improved strength of the whisker composites. The higher strength of composite No 4 when compared to that of No 3 is partly due to the enhanced densification behaviour associated with $\mathrm{ZrO}_{2}$ dispersions in cordierite. 
(d) TZP/SiC whisker composites

The TZP matrix consisted of tetragonal grains, typically $<0.5 \mu \mathrm{m}$ in size, this microstructure being a result of the short time and low temperature of the hot-pressing. No crystalline phases were detected other than $t-\mathrm{ZrO}_{2}$ and $\mathrm{SiC}$. An amorphous phase at the whisker matrix interface, 1-5 nm thick, was observed in TEM /11/. In some cases, glassy pockets had formed adjacent to the whiskers (Fig. 6 ).

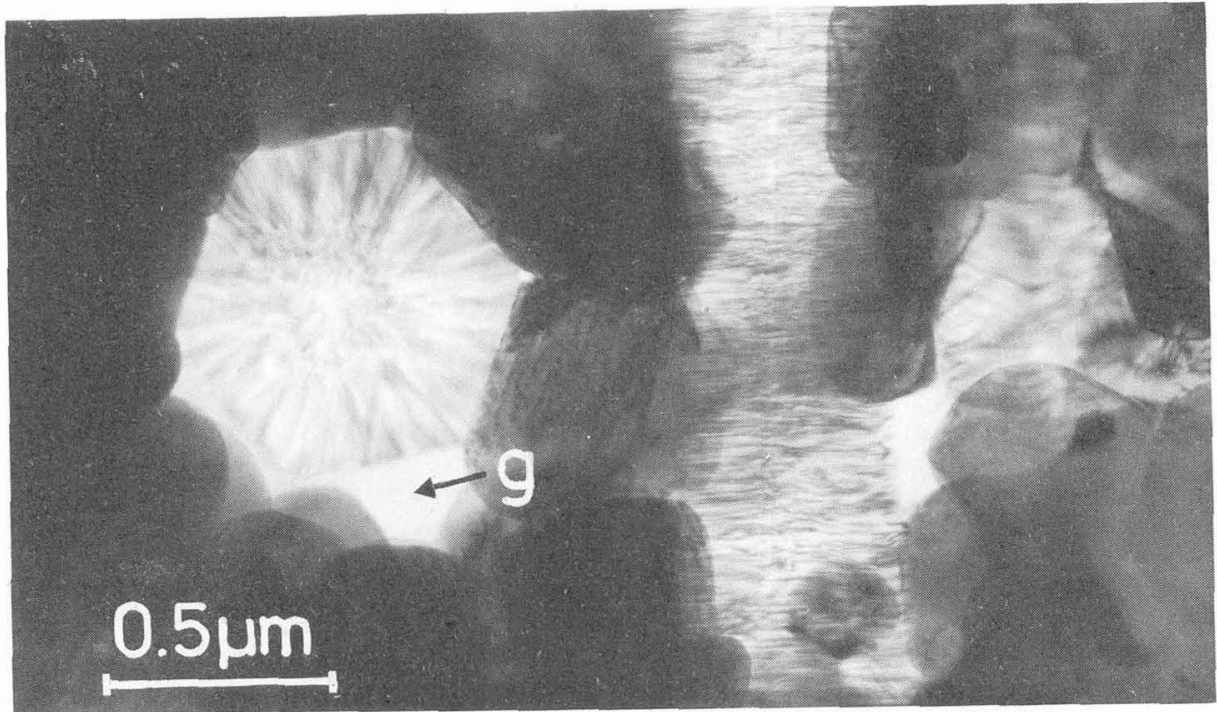

Fig. 6 - Dark-field TEM of SiC whisker/TZP composite showing glass pockets ( $g$ ) near radial whisker cross section.

Table 5: Strength and toughness of TZP/SiC whisker composites.

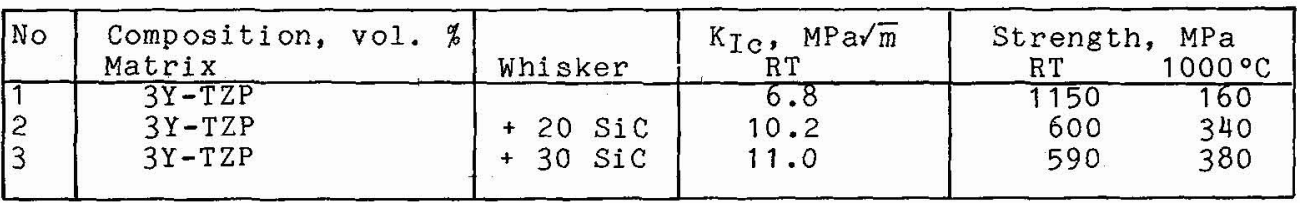

The toughness values and strengths of $3 Y-T Z P$ with 0,20 and 30 vol. \% $\mathrm{SiC}$ whiskers are given in Table 5. The matrix shows the characteristic properties of high-strength TZP with relatively low toughness. The latter may be attributed to the small size of the t- $\mathrm{ZrO}_{2}$ grains which prevents their transforming on stress loading. Thus, the increase in fracture toughness of the whisker composites is assumed to originate from the whiskers where crack deflection appears to be the dominant toughening mechanism.

Whisker debonding and pull-out at room-temperature was rarely observed, probably due to the strong interfacial bonding, and so did not contribute much to the toughening. The bond strength may result from chemical bonding, thermal mismatch strains and interfacial roughness. Only in cases where the whiskers were nearly parallel to the fracture plane did some debonding take place. In all cases, the matrix fracture was predominantly intergranular. 


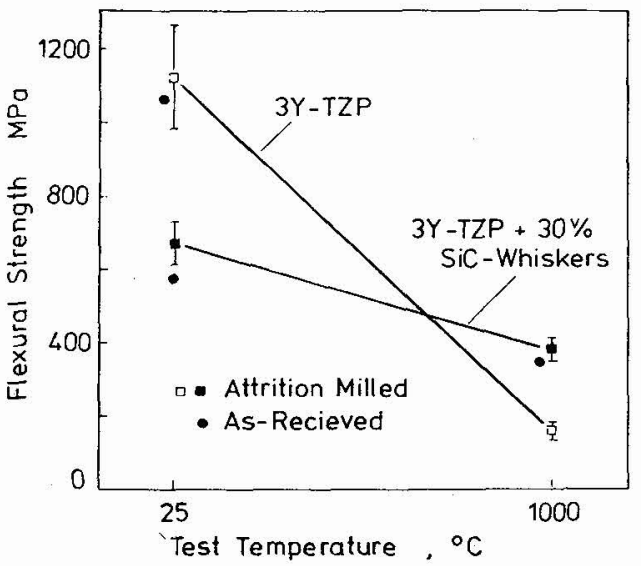

Fig. 7 - Flectural strength of TZP with and without Sic-whisker reinforcement. Thermal mismatch stresses reduce the strength at RT, while modulus load transfer becomes effective at $1000^{\circ} \mathrm{C}$.

The fracture strength is reduced to almost half the TzP matrix strength by the incorporation of whiskers because of the high tensile matrix stresses due to the thermal mismatch $\left(\alpha_{\mathrm{TZP}}=11 \mathrm{MK}^{-1}\right)$.

The situation is markedly different at high temperatures. At $1000^{\circ} \mathrm{C}$, the strength of the whisker composite is nearly twice that of the TzP matrix (Fig. 7). The thermal mismatch stresses are much lower than at room temperature and the interfacial layer has sof tened to the extent that some whisker pull-out (Fig. 8) can take place.
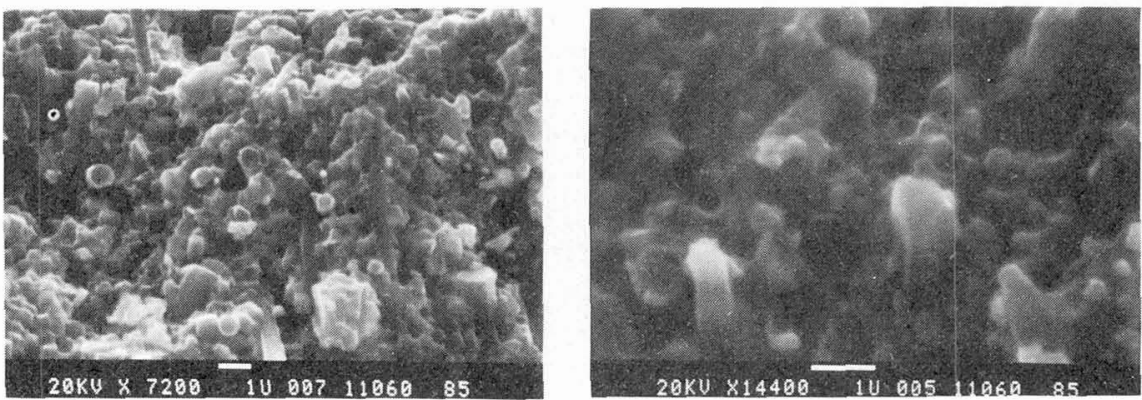

Fig. 8 - Scanning electron micrographs of TZP/30 vol. \% whisker composites fractured at $1000^{\circ} \mathrm{C}$. Some debonding and pull-out occurred.

In samples annealed for $120 \mathrm{~h}$ at $1030^{\circ} \mathrm{C}$ in air, the thickness of the amorphous layer increased drastically at the interface ( $50 \mathrm{~nm}$, Fig. 9) and between the TZP grains near SiC whiskers. Besides Si and Zr, the glasses phase contained $Y$ and some Al. The formation of ZrSiO4 was not observed. Furthermore, most of the grains close to the whiskers were transformed to $\mathrm{m}$ symmetry with microcracks along the grain boundaries. This can be explained by the oxidation of SiC whiskers under the annealing conditions contributing to the amorphous silicate phase and by dissolution of $\mathrm{Y}_{2} \mathrm{O}_{3}$ into the glassy phase, leading to $Y$-depletion of the $t-\mathrm{ZrO}_{2}$ grains which then easily transform. Microcracking is then caused by the transformation and possibly by some co pressure build-up. 


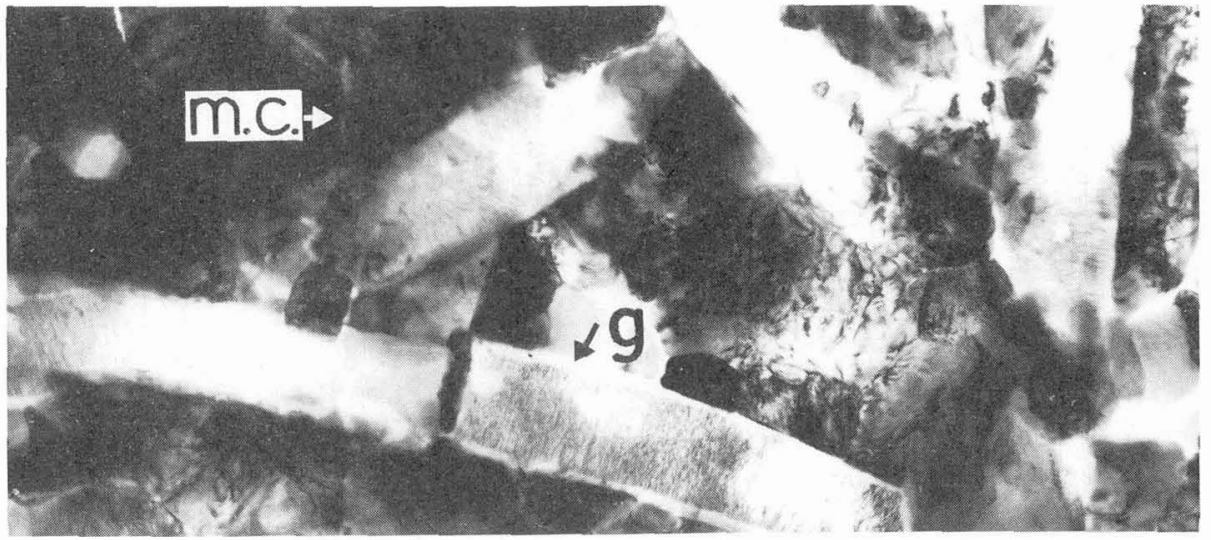

Fig. 9 - TZP-30 vol. \% SiC-whisker composite annealed for $120 \mathrm{~h}$ at $1030^{\circ} \mathrm{C}$ in air. The glassy interface layer is $-50 \mathrm{~nm}$ thick $(\mathrm{g})$. Almost all grains have transformed to monoclinic symmetry. Some microcracks ( $\mathrm{mc}$ ) are visible.

\section{IV - CONTROL OF THERMAL MISMATCH}

In oxide ceramics with coefficients of expansion larger than that of SiC, thermal mismatch stresses are produced on cooling the composite from the preparation temperature which can considerably decrease the strength. These detrimental stresses, however, can be reduced by utilizing a proper amount of thermally transformable Zr02. The principle of controlling the thermal mismatch stresses by this method is explained in Fig. 10. This schematic diagram shows the temperature dependence of the average residual matrix stresses without $\left(v_{0}\right)$ and with $\left(\mathrm{v}_{1}, \mathrm{v}_{2}\right)$ two different volume fractions of transformable $\mathrm{ZrO}_{2}$. The matrix stresses in the composite without transformable $\mathrm{ZrO}_{2}$; i.e., containing only retained $t-\mathrm{ZrO}_{2}$, are tensile at room temperature for $\alpha_{m}>\alpha_{w}$, while the stresses at $v_{1}$ are just balanced and those at $v_{2}$ are compressive. The average matrix stresses at $T<M_{f}$ (martensite finish temperature, $\sim 700^{\circ} \mathrm{C}$ ) can be estimated from:

$$
\sigma_{m} \mathrm{~T}=\frac{\left[\left(\alpha_{m}-\alpha_{\mathrm{W}}\right)\left(\mathrm{T}_{\mathrm{g}}-\mathrm{T}\right)-\varepsilon^{\left.\mathrm{T}_{\mathrm{v}}\right] \mathrm{E}_{\mathrm{W}} \mathrm{W}}\right.}{1+\mathrm{w}\left(\mathrm{E}_{\mathrm{W}} / \mathrm{E}_{\mathrm{m}}-1\right)}
$$

where $E_{\mathrm{m}}(-400 \mathrm{GPa})$ and $E_{\mathrm{W}}(\sim 580 \mathrm{GPa})$ are the matrix $\left(\mathrm{Al}_{2} \mathrm{O}_{3}-\mathrm{ZrO}_{2}\right)$ and whisker (SiC) Young's moduli, $w$ is the whisker volume fraction and $\mathrm{T} g\left(-1200^{\circ} \mathrm{C}\right)$ the temperature below which interfacial relaxation no longer takes place. $\varepsilon^{T}$ is the dilational transformation strain.

The method was tested with composite No 6 (Table 2). While a whiskerfree $\mathrm{Al}_{2} \mathrm{O}_{3}$ with 40 vol. \% $\mathrm{m}-\mathrm{ZrO}_{2}$ (No 5) was heavily cracked due to the large volume change ( $-5 \%)$ associated with the zirconia transformation, the same system when used as matrix with 20 vol. \% SiC whiskers exhibited both high $K_{I c}$ and strength. Since the two-phase matrix is not transformation toughened, the enhanced performance, especially in strength, has to be attributed to the reduced thermal mismatch stresses in the matrix. The residual stress in the No 6 composite is $-190 \mathrm{MPa}$, hence compressive. Even composites consisting of ${\mathrm{m}-\mathrm{ZrO}_{2}}_{2}$ as the only matrix phase could, with 20 vol. \% SiC whiskers, be fabricated with high toughness (No 8 ). 


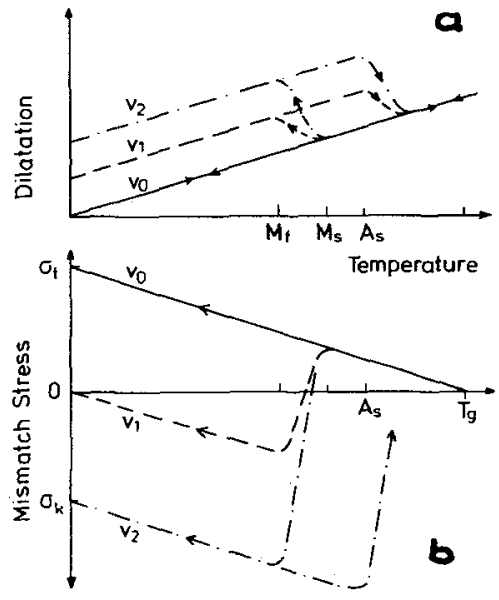

Fig. 10 - 1) Schematic dilatometer curve of a whisker composite without $\left(v_{0}\right)$ and with two different volume fractions of thermally transformable $\mathrm{ZrO}_{2}$ $\left(v_{1}, v_{2}\right)$.

b) Average residual matrix stresses in the whisker composite for $a_{m}>\alpha_{W} . M_{S}$ and $M_{f}$ are the martensite start and finish temperature, $A_{S}$ the austenite start temperature.

\section{$V$ - CONCLUSIONS}

1. The thermal mismatch stresses strongly affect the strength of the composites, e.g. the room-temperature strength of TZP is reduced, while that of mullite and cordierite based composites is increased by the incorporation of SiC whiskers. The strength at $1000^{\circ} \mathrm{C}$ of TZP and cordierite was considerably enhanced by the incorporation of SiC whiskers.

2. The fracture toughness of all oxide ceramics studied was enhanced by the incorporation of SiC whiskers. The dominant toughening mechanism appears to be a crack deflection.

3. An additional toughness contribution may result from the interaction of the stress-induced transformation and the whisker reinforcement.

4. The thermal mismatch stresses in TZP- and $\mathrm{Al}_{2} \mathrm{O}_{3}$-based composites can be reduced by adding an appropriate amount of thermally transformable $\mathrm{ZrO}_{2}$.

VI - ACKNOWLEGMENT

The authors thank $M$. Rühle for the TEM investigations and K.-L. Weisskopf for helpful discussions. Further thanks are due to H:-Y: Liu for the mullite/whisker experiments.

\section{REFERENCES}

T1/Claussen, N., Rühle, M. and Heuer, A.H. (eds.), Advances in Ceramics, vol. 12, The American Ceramic Society, (1984).

/ 2/ Prewo, K.M. and Brennan, J.J., J. Mat. Sci. 15 (1980) 463.

/ 3/ G.C. Wei and P.F. Becher, Am.Ceram. Soc. Bull., 64, 298 (1985).

/ 4/ P:F. Becher and G.C. Wei, J. Am. Ceram. Soc., 67, C-267 (1984).

/ 5/ N. Claussen, Mat. Sci. Eng., 71, 23 (1985).

/ 6/ B:A. Bender, D. Lewis, W.S. Coblenz and R.W. Rice, Ceram. Eng. Sci: Proc., 7-8, $513(1984)$.

/ $7 /$ Claussen, N. and Petzow, G., Tailoring Multiphase and Composite Ceramics, Plenum Press, N.Y., to be published 1985.

/ 8/ M.V. Swain, Fracture Mechanics of Ceramics, Vol: 7/8, Plenum Press, N.Y. to be published 1985 .

$/ 9 /$ R.N. Cannon and A.G. Evans, to be published in Acta Met.

/10/ K. Tsukuma and M. Shimada, J. Mat Sci., 20: 1178 (1985).

$111 /$ N. Claussen, K.L. Weisskopf and M. Rühle, in Ref. $/ 8 /$.

/12/ T.N. Tiegs and P.F. Becher, in Ref. /7/.

/13/ N. Claussen, p. 325, in Ref. /1/. 